\title{
The Context of African Political Thought
}

\author{
by CHRISTOPHER CLAPHAM*
}

THE political ideas put forward by the leaders of the new states provide one of the most popular entrées to African politics, and they have now received a good deal of attention. This is understandable enough. Many African leaders are highly articulate, and their views, embodied in frequent speeches and writings by those who control the information media, are-unlike so much other information-easily accessible. The value and significance of these ideas may well have been exaggerated, but even so they cannot simply be ignored.

The difficulty is that any attempt to use such ideas to interpret or explain political reality raises acute problems concerning the relationship between the actual practice of politics and the language which its practitioners use to describe it. Such problems include the sincerity, coherence, and objective truth of the formulations which politicians put forward, and-at another level-the functions which they serve within the political systems of which their authors themselves form part. Like other data, political ideas need processing before they can be used; and I shall argue here that much existing writing on what has come to be known as 'African ideology' or 'African political thought' has been vitiated by failures in this respect.

The main assumption which I wish to question is the belief that political statements and opinions-whether expressed by a single leader or harvested from a broad field like the single-party state-can usefully and validly be brought together to form reasonably coherent intellectual theories; and that by examining such theories and their application we can understand the nature of political ideas and their role in African politics. I shall then try to show that a closer look at the circumstances under which these ideas are expressed, and the purposes for which they are used, is essential to any appreciation of their significance.

* Research Fellow, Department of Government, University of Manchester. 


\section{'THE IDEOLOGIES OF THE DEVELOPING NATIONS'}

One aspect of this intellectual or theoretical approach is expressed in titles which imply or explicitly state that the ideas discussed can be formulated as systematic conceptual schemes meriting the status of ideologies 1 -in whatever sense of that admittedly slippery word. Characteristically, these schemes have taken the form of some variation on the justifications for single-party government-whether it be called developmental nationalism, developmental populism, the single-party ideology, or something else-whose main features are both familiar and easily summarised: the governing party is said to express a fundamental national unity, from which class antagonisms are absent; any opposition to this party is regarded as divisive and hence illegitimate, and tends to be associated with imperialist conspiracy, or with a tribalism which is itself the result of colonialist divide-and-rule policies; the party is claimed to be democratic since it represents all the people, and it is the instrument for mobilising the people to achieve their development goals. There are, of course, many individual variations of substance and emphasis.

\section{Ideologies as blueprints}

Once formulated, such development ideologies can be interpreted in varying ways. On one view, they are best regarded as conceptual maps with which to order the confused post-independence scene, whose function is systematically to explain the present position of the new states, and to guide and co-ordinate their planned development. ${ }^{2}$ This, too, is a theme which several African leaders have been happy to convey, since it simultaneously helps to encourage a sense of national unity and purpose, gives the impression that the government is in control of the country's destinies, and boosts the intellectual kudos of the leaders themselves.

But whatever the claims made on behalf of these ideologies (from the viewpoint of the politician) it only makes sense to analyse them as ideologies (from the viewpoint of the political scientist) if this can be shown to yield useful explanatory results. If not, then they had better be analysed as something else. Here, the stumbling block is not that the one-party theories do not formally qualify as 'ideologies'. It is

1 E.g. Paul E. Sigmund, The Ideologies of the Developing Nations (New York and London, 1963), and I. Wallerstein, 'The Political Ideology of the P.D.G.', in Présence africaine (Paris), XII, p. 40, 1962.

See Aristide Zolberg, Creating Political Order (Chicago, i 966), p. 39, for the psychological, social, and cultural need for such maps. 
possible to construct from them systems of ideas which generally include the essential components of an ideology, an explanatory and a programmatic element; and, though these incorporate several shady areas of conceptual vagueness and inconsistency, so too does a 'paradigm' ideology such as Marxism. The point is, rather, that the results of treating them as ideologies are so slight. As analyses of social reality in the new states, they can be disproved by showing that they claim a unity which usually does not exist, ${ }^{1}$ and a classless society which is belied by the huge differences in living standards between the élite and the rest. ${ }^{2}$ As precipitants of development, they have beenat the very least-disappointing, for the means to implement them are lacking. ${ }^{3}$ And, as normative guides, they make pretensions which their authors do little to live up to. ${ }^{4}$

It would be otiose to pursue these criticisms in detail, since it is now widely agreed that these ideologies provide little guide to political realities in the new states..$^{5}$ The corollary of this, which is not so widely appreciated, is that any general explanation of the one-party theories as attempts to formulate a coherent ideological response to the problems facing the developing countries is left hanging in the air: by using this explanation as a man of straw, one can secure an empty victory by demolishing the pretensions of African politicians, but this brings one no closer to the actual political uses of their ideas. Remove the man of straw, and the possibility arises that the so-called ideologies may better be understood as conglomerates of the various and perhaps divergent political postures which a leader feels called on to take up. What goes for explicitly claimed ideologies in this context, applies a fortiori to other collections of political ideas.

\section{Ideologies as attitudes}

The term 'ideology' has sometimes been used in a different sense, to denote a set of political attitudes rather than an explicitly formulated theory. This is the approach adopted by Zolberg, for example, in his discussion of the one-party ideology, with the aim of showing that West African single-party leaders share a common view of the political

1 For example, by S. E. Finer, 'The One-party Régimes in Africa: reconsiderations', in Government and Opposition (London), II, 4, July 1967, pp. 494-7.

2 See Giovanni Arrighi and John Saul, 'Socialism and Economic Development in Tropical Africa', in The Journal of Modern African Studies (Cambridge), vi, 2, August 1968, especially pp. $146-7$ and $156-6 r$.

${ }^{3}$ Finer, op. cit. pp. $49^{2-4}$.

${ }^{4}$ There is a large literature, for example, on whether the 'democratic one-party states' are democratic in any useful sense of the word.

5 See Zolberg, op. cit. p. 59, and John Saul, 'Africa', in Ghita Ionescu and Ernest Gellner (eds.), Populism (London, I969), especially pp. I41-5. 
process. ${ }^{1}$ It avoids some of the weaknesses of the blueprint approachin particular, leaders' views may be widely at variance with realityand at the same time apparently salvages from the one-party theories some useful insights into African politics. The political attitudes of élites are certainly a genuine and important field of study; ${ }^{2}$ but to label them ideologies has two serious weaknesses.

The first is that it stretches the term 9deology' so far as to make it almost valueless. It becomes possible, for example, for political scientists to discover ideologies even in cases where the leaders concerned have made no conscious attempt to formulate them, as the following quotation indicates:

Within French-speaking West Africa the Ivory Coast seems to occupy a unique position because although the PDCI achieved a political monopoly earlier than any other organization, none of its leaders, from President Houphouet-Boigny downward, has ever expressed himself in written form on the subject of the one-party ideology beyond a small piece in the party newspaper. Whatever the reasons for this deviation from the usual pattern... it is erroneous to conclude that the Ivory Coast is therefore less 'ideological' than Mali, Guinea, or Senegal, or even that it does not have an ideology. Its ideology is simply less obvious than it is in some other cases, and we must look for it with greater care. ${ }^{3}$

Here, then, the ideology is revealed by culling comments from ministers and the party newspaper, and arranging them so as to fit the themes sounded by more self-conscious ideologues in other countries. ${ }^{4}$ Such an ideology involves no explanatory doctrine, nor any blueprint which is consciously intended to guide or co-ordinate development. Moreover, once it is denied that Guinea (which at least claims to be guided by a consciously formulated ideology) is any more 'ideological' than the Ivory Coast (which does not), then any standard of comparison in these terms has clearly been abandoned. This type of definition makes it difficult to see how any country can lack an ideology, so long as a scholar can find some conceptual string with which to bind together the opinions of its leaders.

A second, more basic objection to the attitude approach is that political utterances-whether or not they are explicitly formulated as

1 Zolberg, op. cit. ch. 2; this approach, at any rate, is implicit in much of Zolberg's discussion, though a formal definition is lacking.

2 On which, let me hasten to add, many of Zolberg's views seem to me admirable.

3 Zolberg, op. cit. pp. 53-4.

4 Even in the 'ideological' one-party states, the ideology generally has to be assembled by its investigator from several speeches or papers, few of which are systematically arranged; see, for example, Wallerstein, loc. cit., or Francis G. Snyder, 'The Political Thought of Modibo Keita', in The Journal of Modern African Studies, v, r, 1967. 
ideologies - cannot be relied upon to reveal what their authors actually believe. They are, after all, designed for public consumption. They do not, prima facie, express what leaders think: they express what leaders want other people to hear. And the striking consistency between the views of leaders from different countries-which Zolberg finds 'the strongest argument in support of their genuine quality'1_-may simply indicate the leaders' common interests in putting over similar propaganda. It is extraordinary, for example, if the one-party ideologies reflect the actual beliefs of their originators, that they pay so much attention to expressions of unity and equality, and so little to disputes and cleavages of whose nature and causes some of them at least must be aware. More bluntly, the gap between fact and theory cannot entirely be explained by the genuine delusions and misunderstandings of African leaders.

\section{The assumption of coherence}

Underlying both the blueprint and the attitude approach is what may be called the assumption of coherence-the assumption that, in any political leader's public statements or writings, there is implicit a coherent schema of beliefs which needs only to be codified. The chief difference between these two approaches is that, once the codification has been carried through, it is put to different uses. It is commoner still to leave it in the form of abstractions such as 'the political thought of Modibo Keita', ${ }^{2}$ or 'the political theories of Julius Nyerere', ${ }^{3}$ which can then come to be regarded as systems of political philosophy, comparable with the 'classical' political theorists such as Hobbes or Rousseau. Yet the question of what the assumption involves has received very little attention.

To the extent that a politician expresses himself on political subjectsand that is his trade-he may be said to have some 'political thought'; but this need not-and generally does not-amount to a coherent system in the sense in which we might speak of 'the political thought of John Stuart Mill'. In this sense, indeed, the views of working politicians are notoriously inconsistent and unreliable. Speaking with a public voice, they have to express acceptable sentiments, and make promises which they often cannot carry out. Their views must change to meet their circumstances, and must inevitably be related to their tenure or prospects of power. Occasional intellectuals in politics may develop

1 Zolberg, op. cit. p. 60.

2 Snyder, loc. cit.

${ }^{3}$ I have myself written a paper under this title, closely comparing Nyerere and Rousseau; in retrospect, I cannot help being rather relieved that it was never published. 
principles which are coherently worked out and impartially applied -though their political life is likely to be short-but if so, these are simply obscured by an assumption which ascribes such consistency to each and every national leader.

Yet, once the assumption is made, a political theory is not hard to devise. Any collection of speeches or occasional papers swiftly reveals those phrases, often jargon, which lend themselves to comparison with political theorists or other politicians. And the consequent risk of coming up with a 'standard' political thought, like the one-party theory outlined earlier, is compounded by the fact that so many of the themes commonly incorporated in political ideologies are ones which almost any leader in office finds himself stating at one time or another. The appeal for national unity is generally irresistible to a government faced-as most governments are-by the fact of disunity. Most governments, too, have to exhort their people to work hard for the nation's goals. Both these themes would carry greater weight, as marks of the one-party ideology, if one could quote examples-from any politician in power, anywhere in the world-of appeals for disunity or for people to work less. Most governments claim to represent the people, if they can get away with it; most are inclined to regard opposition as springing from ignorance and spite; all have to discipline sub-groups, to some extent, in what they conceive to be the common interest. If these themes have been carried to an extreme in some African states, it is more likely to be because there are few restraints from the political culture and institutions than because African leaders have an 'ideology' very different from anyone else's. ${ }^{1}$

A recent article on Amílcar Cabral in this journal vividly illustrates the point. ${ }^{2}$ Cabral's political thought, as it is presented to us, includes (I) a theory that imperialism is a cause of economic stagnation, and will collapse through its inherent contradictions, (2) a theory that traditional elements will coalesce at independence to build a new social order, (3) a theory that the nature of man is related to historical forces, and (4) aspirations of national integration and economic development within the framework of a mass revolutionary party,

1 It would be instructive to see how many elements in the single-party ideology could be matched from the ideology of Harold Wilson. Hard work and unity behind the government in pursuit of national goals are certainly there ('it means putting Britain first'); so are the conspiratorial view of opposition ('this tightly knit group of politically motivated men') and the fervent belief in the value of economic development ("the white heat of the technological revolution'). Threats directed at irresponsible sub-groups such as the trade unions are also familiar, and there are even occasional hints of an appeal to the classless society.

2 Ronald A. Chilcote, 'The Political Thought of Amílcar Cabral', in The Journal of Modern African Studies, vi, 3, October 1968. 
guided by democratic centralism. The whole approximates to a generally applicable model of 'developmental nationalism'.

Yet the impression of coherence which this outline gives is immediately dispelled once the means used to create it are examined; instead of a 'political thought', we find a series of planks from several barely consistent platforms. When we are told that 'Cabral's view of man is related to his perception of historical forces', for example, this amounts, simply and directly, to his assertion that Portuguese imperialism has resulted in the exploitation of the African, and in the deprivation of 'the fundamental rights of man, written into the Charter of the United Nations' $;{ }^{1}$ this is doubtless true, and any nationalist leader would be bound to claim it as true, but it does not add up to a view of man, and the idea that it does can only result from a feeling that such a view is somehow necessary to 'political thought'.

Cabral's theory of imperialism is another example; it is evidently not Marxist, for it denies any economic development which could lead to inherent contradictions, and sense can be made of it only if it is regarded as a compound of ( $\mathrm{I}$ ) a useful Marxist phrase, which may help Cabral to present himself as a revolutionary leader, (2) the need to deny that imperialism has done anything for Portuguese Guinea, and (3) the need to encourage supporters with an assurance of ultimate victory. An analogous mixture may be found in the two adjoining sentences:

Any individual or group favouring 'colonialism, imperialism, or the destruction of the unity of the people' would be deprived of their fundamental liberties. Free general elections would be based on universal, direct, and secret suffrage. ${ }^{2}$

Again, I must make a disclaimer: my aim is not to denigrate Cabral, whose nationalist career commands admiration, but to show the deficiencies of forcing his writings into an intellectual framework which is inappropriate to them.

\section{The class approach}

Some scholars have suggested that the ideas put forward by African leaders may be expressions of the class interests of ensconced and exploitative élites. ${ }^{3}$ This has two marked advantages over previous approaches: it brings a much-needed breath of cui bono?-who gains?

1 Ibid. p. $3^{81}$; it is not clear from the context whether it is Cabral or Chilcote who believes that these rights are to be found in the U.N. Charter.

2 Ibid. p. 383 .

${ }^{3}$ See Saul, op. cit. and Arrighi and Saul, loc. cit. 
-where claims have too often been taken at face value; and it treats these claims not as theoretical models, but as tools within a process of political competition. However, it provides no general framework either for the one-party cluster of ideas or for African 'political thought' as a whole. This is clear from the absence of any correlation between élite exploitation and the use of single-party ideas. Similar (though not of course identical) ideas are expressed, say, in Nkrumaist Ghana (which in the Arrighi/Saul analysis counts as an exploitative system) and in Tanzania (which does not), and hence the same ethic of solidarity can equally well be utilised for maintaining the status quo in one country, and for mobilising mass development in another $;^{1}$ furthermore, the states most often accused of élitist exploitation (such as Kenya and the Ivory Coast) are generally those which make least use of ideological language. In the next section, I shall therefore outline a more generally applicable approach to African political ideas.

\section{AN ALTERNATIVE APPROACH}

This alternative approach studies African leaders in the situations which face politicians the world over-situations which constantly call for a response. The immediate deadline may be an address to an O.A.U. meeting or a gathering of the party women's league-even the need to produce something for a foreign anthology of African political thought. ${ }^{2}$ Beyond that, the leader must defend his decisions, rally his supporters, discomfit his rivals, avoid giving offence to potential allies, pour scorn on accepted enemies. He must try to guide the responses of other actors in the political system, just as his own responses are partly determined for him. Political utterances and ideas-at least when they are used by politicians-are one weapon in this counterplay of pressures; ${ }^{3}$ if they are to further our understanding of African politics, they must therefore be looked at in this context.

In order to turn these contextual influences into a manageable tool, I find it helpful to examine them through two components of political utterances, purpose and language, and through one element in the context itself, the audience, which is specific and important enough to be worth distinguishing.

The purpose is the essence of any political utterance, in that this is what a politician has in mind when he uses particular expressions or

I As Saul makes clear, op. cit. p. 146.

2 This seems to be the basis, for example, of James Duffy and Robert A. Manners, Africa Speaks (Princeton, 1961).

${ }^{3}$ Not the only one: corruption and force are others; but words are cheap. 
ideas; his purposes in turn are related to his political situation, and they operate at several levels of generality. Before independence, the most generalised purposes characteristically consist of demands for independence from the colonial power, and for support from the African population; after independence, appeals for support predominate. More detailed purposes include the secondary objectives used to elicit this support-which may differ between a one-party state, a multi-party system, and a military régime-and specific government policies. At the lowest level, there may be local purposesbuilding a school, diversifying agricultural production-which do not directly feed back into the political system.

Language, in comparison, is no more than a subsidiary consideration, though it imparts a strong flavour to the political purposes, and goes far to explain apparent differences between one speaker and another-between the Marxist terminology favoured by Sékou Touré, the liberal socialism of Nyerere, or the philosophical approach of Senghor. ${ }^{1}$ Hence many of the most overtly 'ideological' elements in a speaker's vocabulary - such as references to the political philosophers who provide him with modes of expression-are no more than linguistic clothing for purposes which might equally well be expressed in different ways. The P.A.F.M.E.C.A. charter claims that 'freedom is our birthright, self-government our heritage' $;^{2}$ the fundamental purpose of this is little different from that of a Marxist-oriented leader claiming to lead the African proletariat against a colonial bourgeoisie. However, the distinction between purpose and language, though useful, is not clear-cut; in any political utterance the two are closely enmeshed, in ways which only the precise context can make clear.

The audience shapes political utterances partly in that a leader has different things to ask of different audiences, partly in that the audience makes him express his purpose in different ways. One week, he addresses the United Nations, in the hope of advancing the liberation of southern Africa, and winning international recognition for his statesmanlike attitude; the next, he gives a talk to university students, with the intention of warding off a threatened riot and convincing them that the government (despite malicious rumours) is still devoted to the welfare of the common man. The first occasion calls for a steadfast defence of the Universal Declaration of Human Rights, the second for

1 This point has been recognised since the first studies of this subject, as in Thomas Hodgkin, 'A Note on the Language of African Nationalism', in Kenneth Kirkwood (ed.), St Antony's Papers Number 10 (London, I96I).

2 Charter of the Pan African Freedom Movement for East and Central Africa, as quoted by Hodgkin, ibid. p. 26. 
harsh warnings to a small clique of irresponsible agitators; neither, incidentally, is much evidence of an ideology. When speaking to a gathering of paramount chiefs, he is likely to stress the ways in which old and new authorities can work together for nation-building; if he wishes to abolish chieftaincy, he will probably label it as undemocratic, and choose some other occasion.

Political ideas, clearly, are not determined by these influences. Leaders put forward different ideas and adopt diverging policies, even under very similar circumstances. Nyerere's attempts to implement the Arusha Declaration show that ideas can take an active role in creating pressures on the environment, as well as a passive one in reacting to them. But this does not affect the basic point: in order to understand the Arusha Declaration - to pursue this example- it is not very helpful to seek out Nyerere's political thought, to elicit his view of the nature of man, or to compare him to Rousseau; it is helpful to look at his attempts to arrest incipient class formation, to retain the support of the peasantry, or to contain rival views within T.A.N.U.

The negative advantage of this approach is that it avoids the pretensions, and hence the weaknesses, of the 'ideological' one. The view that African political ideas should accurately portray social reality in the new states becomes redundant. Quite the contrary, sometimes. An appeal for unity, in which an assertion of existing unity is an appropriate rhetorical device, may be the most suitable response to a crisis marked either by vertical or by horizontal cleavage; and, in such a case, it is equally unhelpful either to accept the assertion as a factual description, ${ }^{1}$ or to ridicule it because it is factually inaccurate. ${ }^{2}$ Or again, 'populist' utterances may be needed to soften the realities of a situation in which power is inevitably exercised by a very small élite. There is a tendency here to reflect predicaments by proclaiming their non-existence.

Furthermore, the ambiguities and inconsistencies which are so glaring in a blueprint are only to be expected in attempts to grapple with changing situations; and the inconsistencies themselves may be created by taking ideas to a level of generality which their actual functions do not require; the eclecticism of African political theories, for instance, has often been remarked, and can be explained by the fact that the politicians' purposes include a number of different appeals directed at different audiences. As for the sincerity of the ideas, and their authors' ability to live up to them, these do not have to be relied on:

1 As Saul, loc. cit. pp. $14^{\mathrm{I}-3}$, belabours Worsley for doing.

2 As Finer does, loc. cit. pp. 494-9. 
any politician must manipulate symbols, press forward claims, which he may deeply believe in, which he may have persuaded himself to believe in, or which he has simply produced for the occasion; there is no reason to suppose that African politicians are much different from others in this respect, and no call for concern if they turn out to be the same.

A positive advantage is that the suggested approach can be applied not just to the one-party cluster of ideas - which have so far monopolised writing on this subject to an unwarranted extent-but to the whole range of political utterances. This can be illustrated by looking at the arguments used by African leaders to claim power before independence and to retain it thereafter. Before independence, as I have suggested, two main purposes and audiences had to be combined: $(a)$ demands to the colonial power and international opinion for independence, and (b) appeals to the African people for support.

For the first of these purposes, there were great advantages, at any rate in the British colonies, in liberal democratic forms of expression. By talking of rights, consent, and self-determination, deploying ideas with which the colonial government was broadly in sympathy, African leaders were able to use their indigenous numerical majority as a lever against the colonial power. To accept this language involved accepting individual rights against the state, which Africans were understandably quick to claim when threatened by the colonial régime, and hencemore or less explicitly-the right to form competing political organisations. Where the colonialists were less amenable to African pressure, nationalists could resort to 'national liberation front' arguments, which by-passed the colonial power and made intensified appeals elsewhere.

The appeal for support demanded rather different arguments. Unity is the first requirement for a mass movement challenging an élitetrade unions are in much the same position. Arguments can therefore be selected, systematically or at random, from the communal approach to political life which stretches from Jean-Jacques Rousseau at one extreme to Robespierre at the other. Here the idea that individuals could have rights against the leadership, or set up rival parties to it, was less attractive, though it sometimes had to be accepted in order to meet colonial expectations. The classic example of this dilemma is Kwame Nkrumah's claim that 'I have always expressed both in public and in private that we need a strong and well-organised Opposition Party in the country and the Assembly.' ${ }^{1}$

1 At a C.P.P. rally in Accra, June 1955, quoted from Dennis Austin, Politics in Ghana (London, 1964), p. $31 \mathrm{n}$. 
The prominence given to those arguments which have been lumped together under the heading of the 'one-party ideology' can largely be explained by the predominance of the second purpose, the appeal for African support, at the expense of the first, once independence had been secured. The ends which the liberal democratic arguments had promoted had been achieved; the audience at which they were principally directed had gone away; the nationalist parties which had employed them had been in opposition, and were now in government. And the arguments for unity, the denial of individual rights, democratic centralism, and the rest, are par excellence government arguments, which can easily be employed to maintain the government in power, and to justify it in doing whatever it wants to do.

This has not prevented the liberal arguments from being used still whenever they can be given a job of work to do. One example was in Nigeria, where the unity arguments were implausible, and politicians had to fall back on regional bases for support. Especially, however, they have been used in equivalents to colonial situations, notably over southern Africa. Thus we find the following language in a manifesto issued in 1969 by 14 African states, including ones with such differing internal legitimations for their Governments as Ethiopia, Malawi, Tanzania, and the Central African Republic:

2. By this Manifesto we wish to make clear, beyond all shadow of doubt, our acceptance of the belief that all men are equal, and have equal rights to human dignity and respect, regardless of colour, race, religion, or sex. We believe that all men have the right and the duty to participate, as equal members of the society, in their own government. We do not accept that any individual or group has any right to govern any other group of sane adults, without their consent, and we affirm that only the people of a society, acting together as equals, can determine what is, for them, a good society and a good social, economic, or political organization. ${ }^{1}$

Again, to labour a point, I am not suggesting that African leaders are necessarily insincere in using such language in this context. Rather, their purpose is to make an appeal-for the liberation of southern Africa-and this is the appropriate means for recommending it to a western audience.

These examples, deployed on a continental scale, have inevitably given a simplified over-all impression which detailed investigation does not justify. Different countries, circumstances, or types of government call forth cross-cutting arguments. For instance, newly installed military governments are prone to call in the spectre of civil war to justify their

1 From the text advertised in The Times (London), 22 May 1969 , by the Zambia High Commission. 
seizing power. The National Reformation Council in Sierra Leone declared that 'actions and utterances of political parties and leaders have resulted in tribal factions and brought about a situation which has led to an almost total breakdown of law and order, bloodshed and imminent tribal war'; Colonel Eyadema in Togo referred to political confusion which had caused a 'psychosis of civil war'; ${ }^{1}$ and General Soglo used a similar justification in Dahomey. ${ }^{2}$ It would be easy enough to call this a Hobbesian argument, and so in a sense it is. Only it does not function as part of any general conception of human nature or of government responsibility, but rather as a language appropriate to back up military appeals for support.

At the national or sub-national level, arguments tend to become still more closely connected to the political circumstances which give rise to them. Most of the controversies over federalism, for example-whether constituent units should be big or small, which powers should be centralised and which devolved-very soon boil down to a tussle between interested parties; the many Nigerian discussions of the issue immediately spring to mind.

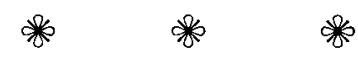

We find, then, a situation in which certain arguments are available to support various views on important questions concerning how governments should be chosen, what their powers and duties should be, how these should be performed. These can, so to speak, be plucked by any politician from the air he breathes, and marshalled, within the broad limits of plausibility, to fit his own situation and inclinations, the audience he is facing, and the purposes he wants to achieve. And, since the number of arguments is limited, they fairly often correspond with those which have been ordered and expounded by political philosophers in the past - whether by coincidence, similarities of situation, or conscious imitation. Little is to be gained from treating 'the ideologies of the developing nations' as anything more than this.

1 The Times, 27 March and 14 January I967.

2 See Le Monde (Paris), 28 December I 665. 